\title{
'The Last Coachman', the Trio of Risk Factors: Alcohol, Tobacco and Traffic Accidents
}

"O Último Cocheiro", o Trio de Factores de Risco: Álcool, Tabaco e Acidentes de Viação

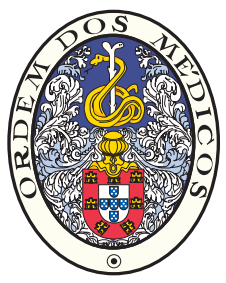

Rui Tato MARINHO1,2

Acta Med Port 2014 May-Jun;27(3):406-407

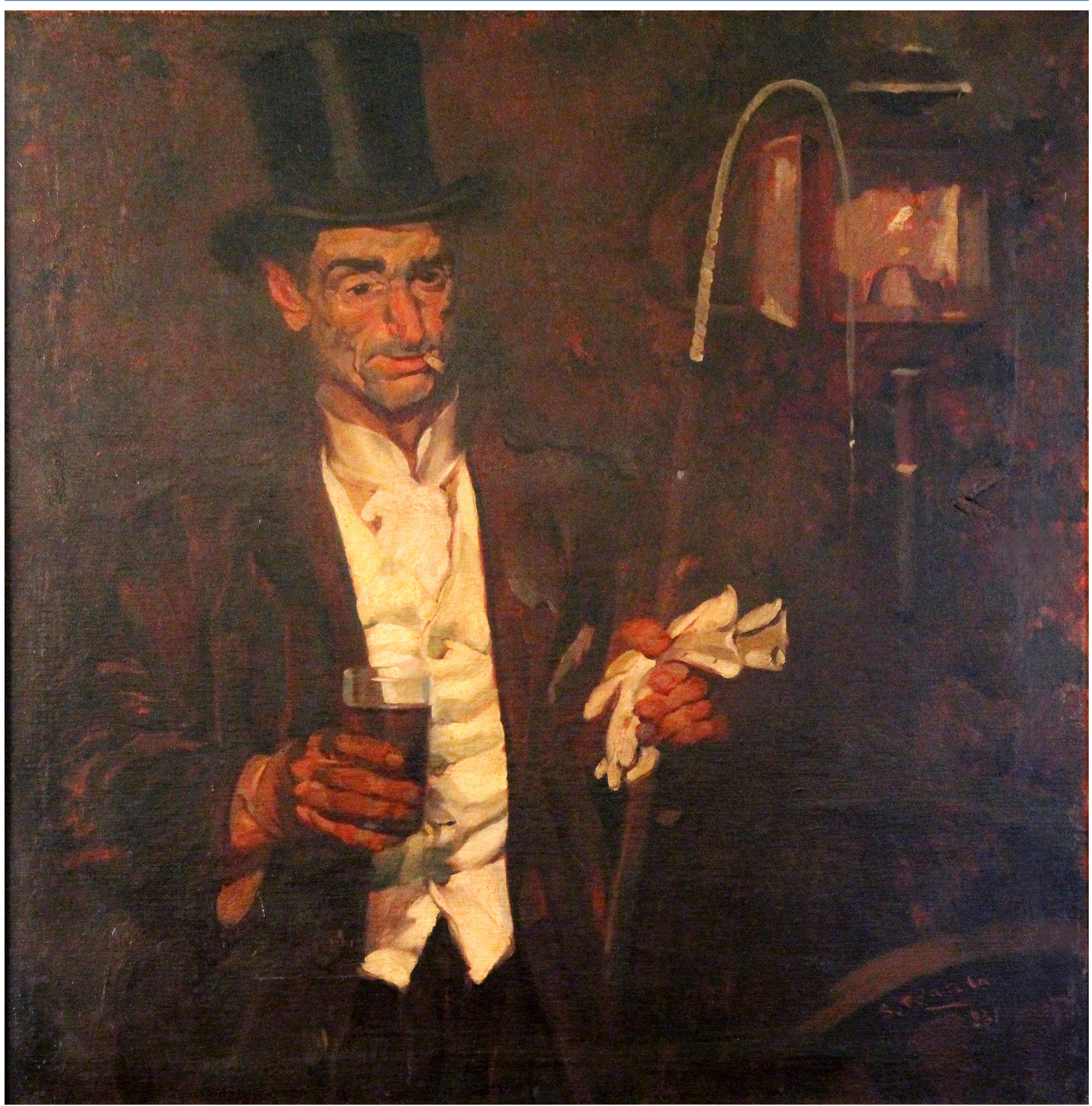

Figure 1 - "O Último Cocheiro", Severo Portela Júnior, 1931, Óleo sobre tela, 1000 x 985cm. Museu da Cidade de Lisboa, Palácio da Mitra. Fotógrafo: José Avelar.

1. Editor-Chefe. Acta Médica Portuguesa. Lisboa. Portugal.

2. Serviço de Gastrenterologia e Hepatologia. Hospital de Santa Maria. Centro Hospitalar Lisboa Norte. Lisboa. Portugal.

Recebido: 15 de Junho de 2014 - Aceite: 16 de Junho de 2014 | Copyright @ Ordem dos Médicos 2014 
Keywords: Alcohol Drinking; Smoking; History, 20th Century; Famous Persons; Paint; Portugal.

Palavras-chave: Consumo de Bebidas Alcoólicas; Fumar; História, Século XX; Pessoas famosas; Pintura; Portugal.

According to the Merriam-Webster dictionary, a 'coachman' is 'a man who drives a coach or a carriage'. The term 'coachman' may actually be applied to the driver of any type of coach, even in times before motor vehicles were in common use. A coachman would provide a public service, wearing clean outfits and politely addressing his customers and patrons.

The painting "The Last Coachman" was authored by the Portuguese artist Severo Portela Júnior, born in Coimbra, in 1898. He lived in Almodôvar, a village in the southern Alentejo region and died in Hospital Santa Maria, in Lisbon, in 1985. Severo Portela Júnior painted several typical aspects of the daily life and landscapes of Alentejo. His legacy has been kept and is represented in a number of Portuguese museums such as Museu Calouste Gulbenkian and Museu do Chiado.

In this representation of a coachman, some symbolic representations are identifiable through the image of a very well dressed man who is smoking and drinking, perhaps red wine, before or after his trip.

By coincidence, this painting from the last century combines three risk factors with an impact on current rates of morbidity and mortality: alcohol, tobacco and traffic accidents. ${ }^{1}$

Excessive alcohol consumption is a major public health issue and has recently been updated by the World Health Organization. ${ }^{2}$ Alcohol abuse contributes to more than 60 medical conditions, with chronic liver diseases (e.g., cirrhosis) and traffic accidents at the top of the list. There is robust scientific evidence supporting a causal relationship between alcohol consumption and these two conditions, identifying them as major causes for years of potential life lost. ${ }^{3,4}$ Binge drinking in young people is also a major issue ${ }^{5}$ and before the age of 18 increases the risk of future dependence, sexually transmitted diseases, traffic accidents, suicide and sudden death. ${ }^{6}$

Tobacco is also a major risk factor for mortality resulting from lung cancer, chronic obstructive pulmonary diseases, cardiovascular and cerebrovascular events. There has been a strong public commitment to reduce smoking habits worldwide, through several kinds of interventions namely law enforcement, control of publicity, prohibition of smoking in public spaces, among others. However, the need remains for some smoking regulations to be suitably addressed, such as those regarding electronic cigarettes ${ }^{7}$ and the implementation of plain packages. ${ }^{8}$

The motorization of our society constitutes a cultural, industrial and socio-economic reality. Car transportation has changed our societies at a huge cost, as one of the major causes of mortality and morbidity is related to traffic accidents. The main factor behind this scenario is the human factor, exemplified by speed excess, alcohol and driving and lack of law enforcement. ${ }^{9}$ Driving slowly saves lives!

In conclusion, these risk factors have been part of our lifestyle, of our so called modern culture. It is imperative that we oppose them and we should rather drive slowly and walk faster (as physical inactivity is also pandemic),${ }^{10}$ drink less quantities of alcohol - one to two drinks a day - and quit smoking. Some of these risk factors of morbidity and mortality have been around for decades and are priority issues that impact health worldwide. It therefore seems fair to ask: does the world also need law enforcement for this trio?

\section{ACKNOWLEDGEMENTS}

Acta Médica Portuguesa and the Portuguese Medical Association thank the Museu da Cidade de Lisboa for the kind grant of rights to reproduce and publish the painting.

\section{CONFLICTS OF INTEREST}

The author declared no conflicts of interest.

\section{FUNDING SOURCES}

None stated.

\section{REFERENCES}

1. World Health Organization. World Health Statistics 2014. [Accessed 2014 Jun 15]. Available at: http://apps.who.int/iris/bitstre am/10665/112738/1/9789240692671_eng.pdf?ua=1.

2. World Health Organization. Global status report on alcohol and health 2014. [Accessed 2014 Jun 15]. Available at: ps.who.int/iris/bitstre am/10665/112736/1/9789240692763_eng.pdf?ua=1.

3. Sheron N, Olsen N, Gilmore I. An evidence-based alcohol policy. Gut. 2008;57:1341-4.

4. Hall AJ, Bixler D, Helmkamp JC, Kraner JC, Kaplan JA. Fatal all-terrain vehicle crashes: injury types and alcohol use. Am J Prev Med. 2009;36:311-6.

5. Hingson RW, Heeren T, Winter MR. Age at drinking onset and alcohol dependence: age at onset, duration, and severity. Arch Pediatr Adolesc Med. 2006;160:739-46.

6. Marques M, Viveiro C, Passadouro R. Uma velha questão numa po-

pulação jovem: o consumo do álcool nos adolescentes escolarizados Acta Med Port. 2013;26:133-8.

7. Duke JC, Lee YO, Kim AE, Watson KA, Arnold KY, Nonnemaker JM, et al. Exposure to electronic cigarette television advertisements among youth and young adults. Pediatrics. 2014 (In press).

8. Hastings $H$. Plain tobacco packaging: a systematic review. [Accessed 2014 Jun 15]. Available at: http://phrc.Ishtm.ac.uk/project _2011-2016_006.html.

9. Redelmeier DA, Tibshirani RJ, Evans L. Traffic-law enforcement and risk of death from motor-vehicle crashes: case-crossover study. Lancet. 2003;361:2177-82.

10. Kohl HW 3rd, Craig CL, Lambert EV, Inoue S, Alkandari JR, Leetongin $\mathrm{G}$, et al. The pandemic of physical inactivity: global action for public health. Lancet. 2012;380:294-305. 
Rui Tato MARINHO

\section{'The Last Coachman', the Trio of Risk Factors: Alcohol, Tobacco and Traffic Accidents \\ Acta Med Port 2014:27:406-407}

Publicado pela Acta Médica Portuguesa, a Revista Científica da Ordem dos Médicos

Av. Almirante Gago Coutinho, 151

1749-084 Lisboa, Portugal.

Tel: +351218428215

E-mail: submissao@actamedicaportuguesa.com

www.actamedicaportuguesa.com

ISSN:0870-399X | e-ISSN: 1646-0758

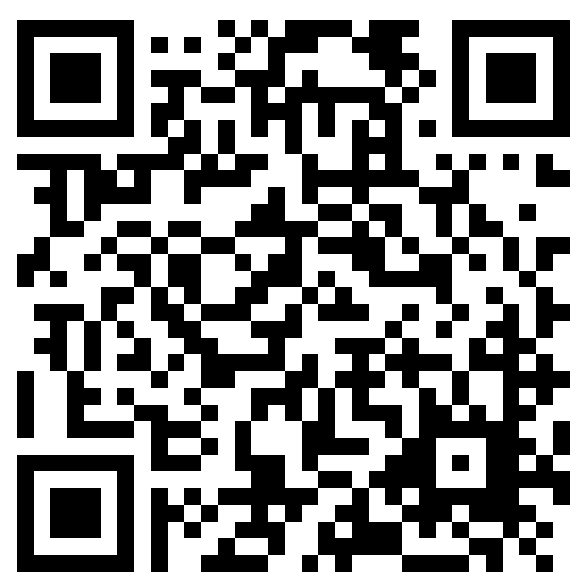

